\title{
Validity and reproducibility of a food frequency questionnaire for children
}

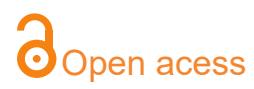

${ }^{1}$ Department of Nutrition of the Federal University of Santa Catarina (UFSC) - Florianópolis (SC), Brazil.

2University Center of Varzea Grande- UNIVAG.

${ }^{3}$ Department of Epidemiology, Faculty of Public Health, USP. São Paulo (SP), Brazil

\section{Corresponding author:} phinnig@yahoo.com.br

Manuscript received: January 2018 Manuscript accepted: April 2018 Version of record online: June 2018

\author{
Patrícia de Fragas Hinnigㄹ, Barbara Grassi Prado², Maria do \\ Rosário Dias de Oliveira Latorre ${ }^{3}$
}

\begin{abstract}
Introduction: A Quantitative Food Frequency Questionnaire (QUEFAC) was developed by Hinnig et al. (2010) to evaluate the usual food consumption of children 7 to 10 years old, since those developed for adults may overestimate the consumption of children. However, its validity and reproducibility must be tested to assert that the instrument has a recognized quality.
\end{abstract}

Objective: To assess the reproducibility and validity of the QUEFAC to children aged 7 to 10 years.

Methods: Reproducibility was tested with 89 children who responded to two QUEFAC's. Validity was tested with 167 children who responded to three 24-hour recalls (reference method) and one QUEFAC. For the evaluation, the paired t-tests, Wilcoxon, intraclass correlation coefficients, weighted Kappa and analysis of the Bland-Altman graphs were used.

Results: For reproducibility, mean differences were observed for all nutrients investigated, correlation coefficients ranged from 0.12 to 0.54 and Kappa values from 0.01 to 0.39 . For validity, mean differences for all nutrients were observed, except for energy and zinc, correlation coefficients ranged from 0 to 0.37 , Kappa values from 0 to 0.27 . Bland-Altman graphs showed a random distribution for most of the nutrients investigated.

Conclusion: The QUEFAC was not valid for evaluation of usual food consumption of the last three months in children aged 7 to 10 years in São Paulo and presented moderate reproducibility for energy, protein, calcium, phosphorus, iron, potassium, magnesium and vitamin B2.

Keywords: food consumption, child, questionnaires, validity of results, reproducibility of results, nutritional assessment. 


\section{INTRODUCTION}

The increasingly early onset of chronic diseases in children is influenced by erroneous dietary practices. This makes it necessary to monitor dietary indicators that assess the habitual food consumption in this age group, with specific instruments that perform this monitoring ${ }^{1}$.

The most common methods for monitoring the food consumption are the Food Record (FR), the 24-hour Food Recall (R24h) and the Food Frequency Questionnaire (FFQ). The FR estimates habitual consumption and should be completed for a long period in children, which requires high cooperation and parents' help, in addition to previous training to complete the registry. The R24h should be completed for several days to gain a representation of usual diet. The standardization and data analysis of the R24h and FR makes it difficult for them to be used for a large number of individuals ${ }^{2}$.

Evaluation of usual diet can be performed by a single application of a specific FFQ for children. Internationally, there are few FFQs designed for children 7 to 10 years old ${ }^{1,3-5}$. In Brazil, the study by Scagliusi et al.6 developed an FFQ for a population of school children from the Brazilian West Amazon, and the study by Matos et $a .^{7}$ created an FFQ for children aged 4 to 11 years from Salvador, Bahia. To our knowledge, there is no FFQ designed to investigate the habitual food consumption

\section{METHODS}

\section{Study type}

This was a methodological study.

\section{Study population}

The reproducibility and validity studies were carried out with children aged 7 to 10 enrolled in public schools in Araraquara / SP and São Paulo City, respectively.

For both studies, the sample size was calculated to be 93 children, using the formula proposed by Machin et $a l .{ }^{10}$, with a test power of 0.9 , an $\alpha=5 \%$ and an expected minimum correlation coefficient of 0.3 . However, in anticipation of possible sample losses, it was decided to select twice as many children (approximately 180).

\section{Inclusion criteria}

Children aged 7 to 10 years old, who had an Informed Consent Form signed by their parents or guardians were included in this study.

\section{Exclusion criteria}

Children younger than 7 and older than 10 years and 11 months were excluded from this study. Children with a cognitive impairment or those who did not have sufficient cognitive ability to respond to the questionnaires were also excluded.

\section{Reproducibility study}

The reproducibility study was carried out in April 2013 in the city of Araraquara, with children aged 7 to 10 years old. The children were selected by two-stage cluster sampling, in which four out of eleven schools were randomly selected and then two grades from each school that contains foods with portions commonly consumed by school-age children in the State of São Paulo.

After the development of instruments that assess food consumption, including the FFQ, it is necessary to evaluate their validity and reproducibility to determine sources of errors inherent to their use. That is to say, the adequacy of the food list questionnaire, and the adequacy of the average assumed nutrient value for each food item and portion size ${ }^{8}$.

Hinnig et al. ${ }^{9}$ proposed a Quantitative Food Frequency Questionnaire (QUEFAC) for children in São Paulo, aged 7 to 10 years, to evaluate habitual consumption, over three months, of energy and macronutrients. Details of the QUEFAC development are described by Hinnig et al. ${ }^{9}$. After a pilot study, the QUEFAC was adapted; it consists of 76 food items and eight consumption frequency options. Only after evaluating the reproducibility and validity of the QUEFAC can the instrument is recognized as a quality tool to be used in the evaluation and monitoring of food consumption changes in longitudinal studies on lifestyle and health at school age.

The objective of this study was to evaluate the reproducibility and validity of the QUEFAC in children aged 7 to 10 years.

were selected. Of the total of 179 children in the sample, twelve were outside of the study's age of interest and were excluded. Of the 167 eligible children, 114 (68.3\%) provided the signed Informed Consent Form; of those 114 children, 20 were unable to respond to QUEFAC, one child left due to illness, two were transferred from school and two were excluded for having food consumption larger than $5000 \mathrm{kcal}$. The final sample consisted of 89 children.

To characterize the sample, a Socioeconomic Questionnaire was sent to the parents or guardians to fill out. This questionnaire was proposed by the Brazilian Association of Research Companies11 and classifies families into social classes according to the Brazilian Economic Classification Criteria (BECC).

The reproducibility evaluation was performed through the application of the QUEFAC at two times, with an interval of 15 days between applications. The QUEFAC was completed via interview, during school hours, and was administered by trained researchers.

Details of the design of the QUEFAC are described in Hinnig et al. ${ }^{9}$. The QUEFAC consists of 76 food items and eight consumption frequency options $(\geq 2$ times a day, 1 time per day, 5 to 6 times per week, 2 to 4 times per week, 1 time per week, 2 to 3 times per month, once a month and never). Each proposed food item has three portion size options that correspond to a small, medium, and large portion size. In completing the QUEFAC, children should respond to how often they consumed a portion of a given food item in the last three months prior to its application.

In order to assist children in reporting quantity, commonly used utensil measures, such as spoons, mugs, cups, skimmer, tongs and ladle were used. A photo album of food portions, developed by Zabotto et al. ${ }^{12}$ was also used 
to assist children to report quantity. A board describing the consumption frequency options contained in the QUEFAC was used at the time of the interview to assist the children in reporting their frequency of consumption. Children who failed to respond to the QUEFAC, for not being able to report their frequency of food consumption, were excluded from the study.

\section{Validity study}

The validity study was conducted from August to December 2013 with children aged 7 to 10 years old. All eligible children who were enrolled in the 2 nd to 5 th year of elementary school at two public schools in the city of São Paulo were invited to participate in the study. Of the 380 children who met the inclusion criteria, 221 (58.2\%) participated in the study by providing an Informed Consent Form signed by their parents or guardians. Of these 221 children, 3 were excluded due to disabilities that made it difficult to interview them. In addition, 1 child moved from the city, 1 was transferred from school and 49 were excluded or unable to respond to the QUEFAC or R24h. Thus, the final sample of children who were able to respond to QUEFAC and to the three R24h was 167.

At both schools, two trained researchers conducted data collection during the school period. To evaluate the validity of the QUEFAC, the application of three R24h questionnaires was used as a reference method, where one application encompassed the weekend. The R24h questionnaires were applied approximately 1 month apart. The QUEFAC was completed at the same time as the 2nd R24h to capture the usual diet of the last three months. Children who did not respond to the three R24h questionnaires were excluded.

A similar strategy to that used in the reproducibility study to assist in reporting food quantity and frequency was used in the validity study. The children who failed to respond to the QUEFAC, for not being able to report their frequency of consumption, were excluded from the study.

The R24h questionnaires were standardized and

\section{RESULTS}

The reproducibility study sample was composed of 89 children, $65.2 \%$ were female, $32.6 \%$ were 8 years old (mean $=9.1$ years, $\mathrm{sd}=1.08$ ) and $65.6 \%$ were in class $\mathrm{C}$ (average salary of $\mathrm{R} \$ 1,147.00$ to $1,685.00$ - equivalent to USD\$ 347.2 to 510.37 ). In the validity study, $57.5 \%$ of the sample were female, $70.6 \%$ were aged 8 to 9 years old (mean $=9.2$ years, $\mathrm{sd}=0.85$ ) and $48.4 \%$ were in class $\mathrm{C}$.

Tables 1 and 2 show the reproducibility results. Statistically significant differences were observed for energy and for all nutrients evaluated, with the means being higher in the 1st QUEFAC. Intraclass correlation coefficients (ICCs) ranged from 0.12 for lipids to 0.54 for calcium, and no statistically significant correlations were found for lipids, carbohydrates, vitamin $\mathrm{C}$ and cholesterol (Table 1). Approximately $44 \%$ of the children were classified in the same tertile of consumption by both applications of the QUEFAC. The weighted Kappa coefficients varied from 0.01 for lipids to 0.39 for zinc (Table 2).

Tables 3 and 4 show the results of the validity study. The nutrient averages were found to be significantly different typed in the NutriQuanti* software and QUEFAC was coded and typed in duplicate in DietSys version 4.01.

\section{Statistical analyses}

Descriptive analyses were performed for sex, age and socioeconomic level. The mean and standard deviation of age, and the proportions of children in each age group, sex and socioeconomic level were calculated.

Food consumption data from the QUEFAC and R24h were adjusted according to the model proposed by Willett and Stampfer ${ }^{13}$. The R24h data were also adjusted for variability. Energy and nutrients were evaluated according to adherence to the normal curve by the KolmogorovSmirnov test. In the reproducibility study, lipid, saturated fat and cholesterol were transformed by logarithms; vitamin $\mathrm{C}$ data was analyzed without transformation, using nonparametric testing. In the validity study, cholesterol was transformed by logarithm and the vitamin $\mathrm{C}$ was analyzed without the transformation.

To evaluate reproducibility, the adjusted energy and nutrient means of the first QUEFAC were compared to the adjusted values of the second QUEFAC using the paired t-test or Wilcoxon. For validity, the adjusted energy and nutrient means of the three R24h were compared to the adjusted values of the QUEFAC using the same analyses.

For reproducibility and validity, intraclass correlation coefficients and $95 \%$ confidence intervals were calculated. In the reproducibility study, energy and nutrient data were classified into consumption tertiles. In the validity study, energy and nutrient data were classified into consumption quartiles and the weighted Kappa coefficient was calculated to verify agreement. Bland-Altman plots were also used to verify the presence of bias and the random distribution of data in the validity study.

Data analysis was performed in Stata, program version 10.0 .

The present study was approved by the Research Ethics Committee of the School of Public Health of the University of São Paulo (COEP / FSP-USP) (protocol 0152.0.207.207-11).

between methods, except for energy and zinc ( $p=0.538$ and $p=0.496$, respectively). ICCs ranged from 0.00 for saturated fat and 0.37 for vitamin $\mathrm{C}$, showing statistically significant weak correlations for energy, protein, calcium, phosphorus, sodium, potassium, magnesium, vitamin B2, vitamin $\mathrm{C}$, and retinol (Table 3). Approximately $70 \%$ of the children were classified in the same quartile or with a difference of 1 quartile. The weighted Kappa coefficients ranged from 0 for lipids to 0.27 for retinol and were statistically significant for energy, protein, calcium, phosphorus, potassium, magnesium, vitamin B2, vitamin C and retinol (Table 4).

Bland-Altman plots were plotted to verify the agreement between the energy and nutrient values of the QUEFAC and R24h. An increase in the difference between the methods, with an increase of the average consumption for energy, proteins, iron, potassium, vitamin B6, magnesium and cholesterol was observed. For the other nutrients, the graph showed a random distribution (data not shown). 
Table 1: Reproducibility of energy and nutrient consumption of the 1st QUEFAC and the 2nd QUEFAC, completed by schoolchildren aged 7 to 10, Araraquara - SP, 2013

\begin{tabular}{|c|c|c|c|c|c|c|c|}
\hline \multirow[t]{2}{*}{ Nutrients } & \multicolumn{2}{|c|}{ 1st QUEFAC } & \multicolumn{2}{|c|}{ 2nd QUEFAC } & \multirow[t]{2}{*}{$\mathbf{p}^{*}$} & \multirow[t]{2}{*}{$\mathbf{r}^{\prime \mathrm{ICC}}$} & \multirow[t]{2}{*}{ ICC (95\%) } \\
\hline & Mean & Sd & Mean & Sd & & & \\
\hline Energy (kcal) & 2395.86 & 733.34 & 2028.67 & 727.75 & $<0.001$ & 0.44 & $0.25 ; 0.59$ \\
\hline Proteins (g) & 95.09 & 15.83 & 81.17 & 16.16 & $<0.001$ & 0.41 & $0.23 ; 0.57$ \\
\hline Lipids (g) & 81.47 & 12.88 & 68.51 & 12.53 & $<0.001$ & 0.12 & $-0.09 ; 0.32$ \\
\hline Carbohydrates (g) & 340.26 & 35.07 & 289.14 & 30.03 & $<0.001$ & 0.13 & $-0.08 ; 0.33$ \\
\hline Calcium (mg) & 774.93 & 188.04 & 658.74 & 153.86 & $<0.001$ & 0.54 & $0.38 ; 0.68$ \\
\hline Phosphorus (mg) & 1501.93 & 209.75 & 1273.64 & 210.20 & $<0.001$ & 0.42 & $0.23 ; 0.58$ \\
\hline Iron (mg) & 16.12 & 3.57 & 13.95 & 3.59 & $<0.001$ & 0.48 & $0.30 ; 0.62$ \\
\hline Sodium (mg) & 3684.06 & 605.46 & 3187.09 & 527.29 & $<0.001$ & 0.25 & $0.05 ; 0.44$ \\
\hline Potassium (mg) & 3350.56 & 623.61 & 2757.72 & 580.98 & $<0.001$ & 0.48 & $0.30 ; 0.62$ \\
\hline Zinc (mg) & 13.40 & 2.38 & 11.44 & 2.72 & $<0.001$ & 0.37 & $0.17 ; 0.53$ \\
\hline Magnesium (mg) & 361.73 & 85.85 & 310.41 & 80.56 & $<0.001$ & 0.52 & $0.36 ; 0.66$ \\
\hline Vitamin B1 (mg) & 2.17 & 0.37 & 1.84 & 0.30 & $<0.001$ & 0.34 & $0.14 ; 0.51$ \\
\hline Vitamin B2 (mg) & 2.27 & 0.41 & 2.03 & 0.46 & $<0.001$ & 0.49 & $0.31 ; 0.63$ \\
\hline Niacin (mg) & 21.94 & 3.35 & 18.74 & 2.97 & $<0.001$ & 0.27 & $0.07 ; 0.46$ \\
\hline Vitamin B6 (mg) & 2.18 & 0.32 & 1.86 & 0.34 & $<0.001$ & 0.22 & $0.02 ; 0.41$ \\
\hline Vitamin C (mg) & 128.59 & 109.00 & 85.46 & 64.11 & $<0.001^{* *}$ & 0.16 & $-0.05 ; 0.35$ \\
\hline Retinol (mcg) & 295.97 & 107.83 & 258.32 & 110.76 & 0.005 & 0.35 & $0.16 ; 0.52$ \\
\hline Saturated fat (g) & 26.58 & 5.52 & 22.21 & 5.20 & $<0.001$ & 0.24 & $0.03 ; 0.42$ \\
\hline Cholesterol (mg) & 277.62 & 107.51 & 221.55 & 75.94 & $<0.001$ & 0.15 & $-0.06 ; 0.35$ \\
\hline
\end{tabular}

${ }^{*}$ Paired t-test; ${ }^{* *}$ Wilcoxon test

Table 2: Tertile classification of energy consumption and nutrients (\%) obtained by 1st QUEFAC and 2nd QUEFAC of students aged 7 to 10. Araraquara - SP, 2013.

\begin{tabular}{lccccc}
\hline Nutrients & Same tertile (\%) & $\begin{array}{c}\text { Difference of } \mathbf{1} \text { tertile } \\
(\mathbf{\%})\end{array}$ & Opposite tertile (\%) & Kappa & p \\
\hline Energy (kcal) & 49.4 & 42.7 & 7.9 & 0.34 & $<0.001$ \\
Proteins (g) & 39.3 & 47.2 & 13.5 & 0.16 & 0.026 \\
Lipids (g) & 30.3 & 51.7 & 18.0 & 0.01 & 0.447
\end{tabular}


Continuation: Table 2: Tertile classification of energy consumption and nutrients (\%) obtained by 1st QUEFAC and 2nd QUEFAC of students aged 7 to 10. Araraquara - SP, 2013.

\begin{tabular}{llcccc}
\hline Nutrients & Same tertile (\%) & $\begin{array}{c}\text { Difference of } \mathbf{1} \text { tertile } \\
(\mathbf{\%})\end{array}$ & $\begin{array}{c}\text { Opposite tertile (\%) } \\
\text { Kappa }\end{array}$ & $\mathbf{p}$ \\
\hline Carbohydrates (g) & 40.4 & 40.4 & 19.2 & 0.11 & 0.089 \\
Calcium (mg) & 52.8 & 36.0 & 11.2 & 0.34 & $<0.001$ \\
Phosphorus (mg) & 41.6 & 44.9 & 13.5 & 0.19 & 0.012 \\
Iron (mg) & 43.8 & 47.2 & 9.0 & 0.26 & $<0.001$ \\
Sodium (mg) & 38.3 & 40.4 & 21.3 & 0.06 & 0.230 \\
Potassium (mg) & 48.4 & 40.4 & 11.2 & 0.29 & $<0.001$ \\
Zinc (mg) & 56.2 & 33.7 & 10.1 & 0.39 & $<0.001$ \\
Magnesium (mg) & 49.4 & 38.2 & 12.4 & 0.29 & $<0.001$ \\
Vitamin B1 (mg) & 40.4 & 36.0 & 23.6 & 0.06 & 0.230 \\
Vitamin B2 (mg) & 51.7 & 38.2 & 10.1 & 0.34 & $<0.001$ \\
Niacin (mg) & 41.6 & 42.7 & 15.7 & 0.16 & 0.026 \\
Vitamin B6 (mg) & 37.1 & 47.2 & 15.7 & 0.11 & 0.089 \\
Vitamin C (mg) & 47.2 & 36.0 & 16.8 & 0.21 & 0.005 \\
Retinol (mcg) & 42.7 & 42.7 & 14.6 & 0.19 & 0.012 \\
Saturated fat (g) & 41.6 & 47.2 & 11.2 & 0.21 & 0.005 \\
Cholesterol (mg) & 48.3 & 36.0 & 15.7 & 0.24 & 0.002 \\
\hline
\end{tabular}

Table 3: Validation of energy and nutrient consumption of schoolchildren aged 7 to 10 , Sao Paulo, 2013

\begin{tabular}{lccccccc}
\hline Nutrients & \multicolumn{2}{c}{ QUEFAC } & \multicolumn{2}{c}{ R24h } & $\mathbf{p}^{*}$ & ricc & ICC (95\%) \\
\hline & Mean & Sd & Mean & Sd & & & \\
Energy (kcal) & 2086.53 & 701.33 & 2119.03 & 421.50 & 0.538 & 0.31 & $0.16 ; 0.44$ \\
Proteins (g) & 84.49 & 14.30 & 81.52 & 9.67 & 0.017 & 0.16 & $0.00 ; 0.30$ \\
Lipids (g) & 68.46 & 10.04 & 77.32 & 6.87 & $<0.001$ & 0.00 & $-0.15 ; 0.16$ \\
Carbohydrates (g) & 300.38 & 23.82 & 272.45 & 21.96 & $<0.001$ & 0.10 & $-0.05 ; 0.25$ \\
Calcium (mg) & 652.35 & 158.75 & 525.75 & 160.44 & $<0.001$ & 0.22 & $0.07 ; 0.36$ \\
Phosphorus (mg) & 1299.71 & 201.61 & 1026.65 & 136.57 & $<0.001$ & 0.17 & $0.02 ; 0.31$ \\
Iron(mg) & 14.13 & 3.51 & 10.99 & 1.84 & $<0.001$ & 0.10 & $-0.06 ; 0.24$ \\
Sodium (mg) & 3241.0 & 512.48 & 3768.30 & 464.63 & $<0.001$ & 0.17 & $0.02 ; 0.32$ \\
Potassium (mg) & 2911.56 & 552.79 & 1994.04 & 309.50 & $<0.001$ & 0.28 & $0.14 ; 0.42$ \\
Zinc (mg) & 11.52 & 2.06 & 11.69 & 2.51 & 0.496 & 0.03 & $-0.13 ; 0.18$ \\
Magnesium (mg) & 320.30 & 82.03 & 200.92 & 38.27 & $<0.001$ & 0.20 & $0.05 ; 0.34$ \\
Vitamin B1 (mg) & 1.91 & 0.29 & 1.05 & 0.20 & $<0.001$ & 0.10 & $-0.05 ; 0.25$ \\
Vitamin B2 (mg) & 1.89 & 0.43 & 1.14 & 0.31 & $<0.001$ & 0.28 & $0.14 ; 0.42$ \\
Niacin (mg) & 19.08 & 2.56 & 15.12 & 2.18 & $<0.001$ & 0.15 & $0.00 ; 0.29$ \\
Vitamin B6 (mg) & 1.86 & 0.34 & 0.77 & 0.15 & $<0.001$ & 0.11 & $-0.05 ; 0.25$ \\
Vitamin C (mg) & 111.66 & 72.69 & 132.53 & 65.24 & $<0.0011^{* *}$ & 0.37 & $0.23 ; 0.49$ \\
Retinol (mcg) & 224.56 & 94.33 & 190.32 & 87.78 & $<0.001$ & 0.23 & $0.08 ; 0.37$ \\
Saturated fat (g) & 21.80 & 4.30 & 23.56 & 2.78 & $<0.001$ & 0.00 & $-0.20 ; 0.11$ \\
Cholesterol (mg) & 230.48 & 91.64 & 239.65 & 40.78 & $<0.001$ & 0.00 & $-0.20 ; 0.10$ \\
\hline
\end{tabular}

${ }^{*}$ Paired t-test; ${ }^{* *}$ Wilcoxon test 
Table 4: Classification, by consumption quartile (\%), of energy and nutrients of schoolchildren aged 7 to 10 , obtained by the QUEFAC and R24h, São Paulo, 2013

\begin{tabular}{lcccccc}
\hline Nutrients & $\begin{array}{c}\text { Same quartile } \\
(\%)\end{array}$ & $\begin{array}{c}\text { Difference of } \\
\text { 1 quartile (\%) }\end{array}$ & $\begin{array}{c}\text { Difference of 2 } \\
\text { quartiles (\%) }\end{array}$ & $\begin{array}{c}\text { Opposite } \\
\text { quartiles (\%) }\end{array}$ & Kappa & p \\
\hline Energy (kcal) & 30.5 & 41.9 & 21.6 & 6.0 & 0.17 & $<0.001$ \\
Proteins (g) & 31.7 & 37.7 & 21.6 & 9.0 & 0.14 & $<0.001$ \\
Lipids (g) & 24.6 & 37.7 & 26.3 & 11.4 & 0.00 & 0.492 \\
Carbohydrates (g) & 28.7 & 37.1 & 24.6 & 9.6 & 0.08 & 0.081 \\
Calcium (mg) & 36.5 & 30.5 & 21.6 & 11.4 & 0.14 & $<0.001$ \\
Phosphorus (mg) & 31.7 & 36.5 & 23.9 & 7.9 & 0.14 & $<0.001$ \\
Iron (mg) & 24 & 44.3 & 19.8 & 11.9 & 0.04 & 0.239 \\
Sodium (mg) & 28.7 & 34.7 & 28.1 & 8.5 & 0.07 & 0.109 \\
Potassium (mg) & 32.9 & 38.3 & 22.7 & 6.1 & 0.18 & $<0.001$ \\
Zinc (mg) & 25.1 & 38.3 & 24.6 & 12.0 & 0.01 & 0.424 \\
Magnesium (mg) & 29.3 & 40.1 & 20.4 & 10.2 & 0.11 & 0.028 \\
Vitamin B1 (mg) & 28.7 & 38.3 & 20.9 & 12.1 & 0.07 & 0.109 \\
Vitamin B2 (mg) & 38.3 & 32.9 & 19.8 & 9.0 & 0.20 & $<0.001$ \\
Niacin (mg) & 26.3 & 38.3 & 25.7 & 9.7 & 0.05 & 0.189 \\
Vitamin B6 (mg) & 28.1 & 36.5 & 23.9 & 11.5 & 0.05 & 0.189 \\
Vitamin C (mg) & 38.3 & 34.7 & 17.4 & 9.6 & 0.21 & $<0.001$ \\
Retinol (mcg) & 40.7 & 36.5 & 13.8 & 9.0 & 0.27 & $<0.001$ \\
Saturated fat (g) & 29.9 & 34.7 & 21.0 & 14.4 & 0.04 & 0.240 \\
Cholesterol (mg) & 26.9 & 38.9 & 21.6 & 12.6 & 0.04 & 0.240 \\
\hline
\end{tabular}

DISCUSSION

The present study verified the reproducibility and validity of a quantitative FFQ developed specifically for children aged 7 to 10 years old in the State of São Paulo. Four main results can be drawn from this study: 1) in general, the energy and nutrient averages evaluated by the first application of the QUEFAC were higher than those evaluated by the second application of the QUEFAC; 2) moderate reproducibility for energy, protein, calcium, phosphorus, iron, potassium, magnesium and vitamin B2 were observed, reproducibility was not observed for other nutrients; 3) the QUEFAC is not indicated to represent the mean of the group consumption for the majority of the investigated nutrients, with the exception of energy and zinc; 4) the QUEFAC was not valid for evaluating the habitual diet of the last three months in children aged 7 to 10 in São Paulo.

Unsatisfactory reproducibility and validity results have been verified in FFQs developed for children, including those aged 7-10-years old. Studies have shown mean correlation coefficients for reproducibility that do not exceed $0.5^{1,3,5,14}$, and for validity the average coefficients are even smaller and do not exceed $0.4^{3,5,7,14}$.

Several factors regarding the unsatisfactory results of reproducibility and validity should be considered, among them the lack of agreement in the literature regarding a satisfactory correlation coefficient. Block et al ${ }^{15}$, Romieu et al. ${ }^{16}$ and Willett ${ }^{8}$ suggest coefficients of 0.3 to $0.7,0.2$ to 0.5 and 0.4 to 0.7 , respectively. Other factors are the lack of a gold standard as a reference method for food consumption and the nature of the methods compared. The FFQ is an instrument to measure usual diet and the FR and R24h are methods that measure current diet, where the latter applied for several days then represents the usual diet of $\mathrm{FFQ}^{17}$.

Moderate reproducibility (ICCs between 0.4 and 0.54 ) was observed for energy, proteins, calcium, phosphorus, iron, potassium, magnesium and vitamin B2. The ICCs in this study (ICC $=0.12$ to 0.54 ) were higher than those reported in a study by Watson et al. ${ }^{14}$ with children in Australia, aged 9 to 16 years ( $r=0.32$ to 0.44$)$, and lower than those observed by Arnold et al. ${ }^{3}$ with children aged 7 to 12 years $(r=0.11$ to 0.69$)$. The mean of the ICC in the reproducibility study was 0.36 , which was higher than that observed in a study by Watson et l..$^{14}(\mathrm{r}=0.32)$ and a study by Preston et al. ${ }^{5}$ (2011) with students from the 5th year of Puerto Rico, Mexico $(r=0.21)$. The low correlations found $(<0.4)$ can be explained by the great variability in intrapersonal consumption and it does not necessarily imply a non-replicable instrument, but it has not provided stable measures over time ${ }^{18}$.

The differences in means observed for all nutrients in the reproducibility study imply an inaccuracy of the QUEFAC in estimating the mean of the group. In addition, higher mean values of nutrients were observed in the first application of the QUEFAC compared to the second application, similar to results found in the literature ${ }^{5,19}$. However, Gibson ${ }^{17}$ reports that the observation of statistically equal means between applications does not indicate good reproducibility of the method, but rather the confounding effect of large intrapersonal variation, which can also be justified in the present study. 
Kappa values in the reproducibility assessment ( 0.01 to 0.39 ) were lower than those found by Watson et $a l .{ }^{14}$ (0.36 to 0.54$)$, demonstrating the lack of precision of the QUEFAC in classifying children by levels of consumption. At one point, a child can be classified as having a high nutrient intake and, at the second application, can be classified as having a low intake of the same nutrient, which implies that QUEFAC is imprecise in classifying children into consumption levels.

High reproducibility values are also questioned by Beaton $^{20}$, who discusses whether correlations found are due to subjects repeating the same errors, rather than consumption being relatively constant over a period.

In the validation study of the QUEFAC, variations of the calculated intraclass correlation coefficient (ICC $=0$ to 0.37 ) were lower than those reported in the literature $3,6,14,21$, but higher than those observed by Matos et $a l .{ }^{7}$ with children in Salvador, where variation ranged from 0.14 to 0.29 . Kobayashi et al. ${ }^{4}$, Watson et al. ${ }^{14}(\mathrm{r}=0.39)$ and Scagliusi et al. ${ }^{6}(\mathrm{r}=0.46)$ found a mean correlation coefficient for their food frequency questionnaires higher than that observed in the present study $(r=0.16)$. A similar mean of 0.21 was found by Matos et $a l .{ }^{7}$ and a lower mean of 0.10 was verified by Preston et al. ${ }^{5}$.

Due to the large variation of the intrapersonal difference ${ }^{4}$, the low correlations that were found reflect a low linear approximation relationship among the methods. According to Nelson ${ }^{18}$ and Gibson ${ }^{17}$, when the correlation is low, there is an increase of poorly classified people at the top or extremes of the consumption distribution, which suggests that at least one of the methods is not valid. Thus, the sensitivity of the questionnaire may be so weak that it may fail to demonstrate associations between diet and disease. On the other hand, good agreement between methods does not necessarily indicate validity, since agreement may be due to both methods presenting similar errors.

Serdula et $a l .{ }^{22}$ suggested that the FFQ is better for classifying individuals into consumption categories, rather than quantifying their habitual consumption. In this case, QUEFAC, in the validity study, showed a low agreement to classify individuals accurately into quartiles of consumption, as observed by weighted Kappa values that did not exceed 0.40 , which was similar to values observed by Watson et al. ${ }^{14}$ and Matos et al. ${ }^{7}$. According to Block ${ }^{15}$, for epidemiological research, the FFQ should at least have a good enough agreement to classify individuals correctly into low, medium and high consumption categories for a certain nutrient to verify which individuals are at higher risk for a certain disease based on observed consumption.

The mean difference test between R24h and QUEFAC was statistically significant for all evaluated nutrients, with the exception of energy and zinc. Similarly, Matos et $a l .^{7}$, observed a statistically significant difference between the averages for all the evaluated nutrients. Therefore, for most of the nutrients investigated, the QUEFAC was not valid for representing the average consumption of the group, which implies that the QUEFAC is not appropriate in studies that relate the prevalence of diseases with consumption in different groups ${ }^{18}$.

Block $^{15}$ describes that verifying validity is extremely difficult when it comes to food consumption since it requires knowledge of actual consumption. If actual consumption values are not available, investigators have to validate their method with a better accepted method, which, in turn, is not validated against the truth. Therefore, according to the definition of validity, it is debatable whether past studies, and the present study, validated an FFQ or simply compared consumption methods.

In addition, the FFQ and the method used as a reference diverge in their nature. The FFQ is a method to measure usual diet, while the R24h measures the individuals' current diet. For this reason, it is unknown whether the methods actually measure food consumption in the same time frame.

Several limitations existed in this study. Although care was taken to avoid food duplicity in food items at the time of development of the QUEFAC, some foods could have been duplicated as they were ingredients of prepared foods that were also part of the QUEFAC. Thus, overestimating consumption could have occurred, which was also discussed by Sahashi et al..$^{23}$ when validating an FFQ in 6 years old children.

Another limitation is the reporting of food consumption by children in this age group, where, due to cognitive immaturity a high number of children were unable to respond to QUEFAC $(\mathrm{n}=54)$, especially when they were asked to report their frequency of consumption. Data were not analyzed for the children who did not report frequency; date was analyzed only for those children who, at the time of the interview evaluation, had at least a "Regular" reporting of frequency of consumption. It is possible that the interviews with the parents obtained better results of reliability and validity; however, the parents did not accompany their children at all times and many children attended full-time school, which may also imply inaccuracies. This makes the decision regarding the best respondent for this age group controversial ${ }^{24}$.

The present study contributes to the area of Nutritional Epidemiology, specifically to the evaluation of food consumption instruments, where this was the first study that verified the reproducibility and validity of a quantitative FFQ developed specifically for children aged 7 to 10 , with portions commonly consumed by this age group, in the State of São Paulo,. Although the results of the validity and reproducibility of the QUEFAC were not adequate for its use, this study contributed to a discussion on the evaluation of sources of errors inherent in this instrument. That is, the possibility of adequacy of the questionnaire's own food list, the adequacy of the average value of the nutrients assumed for each food item, and the sizes of portions of the food. After the adjustments indicated, the QUEFAC can be used to evaluate and monitor the habitual consumption of school-age children and contribute to the evaluation and planning of public policies.

Recent proposals to improve methods of investigating food consumption in children have suggested the concomitant use of the FFQ with the R24h, which brings a new perspective to the use of the FFQ in epidemiological studies ${ }^{25}$. Although the QUEFAC did not 
show satisfactory validity in evaluating habitual diet when applied alone, one can discuss the possibility of evaluating its psychometric properties when it is used concomitantly

\section{CONCLUSION}

In conclusion, QUEFAC was not valid for evaluating the usual diet of the last three months in children aged 7 to 10 in São Paulo. The method overestimated most of the nutrients investigated and did not reflect the group mean for all nutrients, except for with R24h, having the child as respondent and, in a second analysis, the parents, to verify the best respondent of the method.

energy and zinc; it showed poor agreement in classifying children into quartiles of consumption. In addition, the QUEFAC presented moderate reproducibility in reporting energy, proteins, calcium, phosphorus, iron, potassium, magnesium and vitamin B2.

\section{REFERENCES}

1. Rockett HR, Wolf AM, Colditz GA. Development and reproducibility of a food frequency questionnaire to assess diets of older children and adolescents. J Am Diet Assoc. 1995;95(3):336-40. DOI: http://dx.doi.org/10.1016/S0002-8223(95)00086-0

2. Biró G, Hulshof KF, Ovesen L, Amorim Cruz JA; EFCOSUM Group. Selection of methodology to assess food intake. Eur J Clin Nutr. 2002;56 (Suppl 2):S25-32. DOI: http://dx.doi.org/10.1038/sj.ejcn.1601426

3. Arnold JE, Rohan T, Howe G, Leblanc M. Reproducibility and validity of a food frequency questionnaire designed for use in girls age 7 to 12 years. Ann Epidemiol.1995;5(5):369-77. DOI: http://dx.doi.org/10.1016/1047-2797(95)00034-5

4. Kobayashi T, Kamimura M, Imai S, Toji C, Okamoto N, Fukui M, et al. Reproducibility and validity of the food frequency questionnaire for estimating habitual dietary intake in children and adolescents. Nutr $\mathrm{J}$. 2011;10:27. DOI: ttp://dx.doi.org/10.1186/1475-2891-10-27

5. Preston AM, Palacios C, Rodríguez CA, Vélez-Rodríguez RM. Validation and Reproducibility of a Semi-Quantitative Food Frequency Questionnaire for Use in Puerto Rican Children. P R Health Sci J. 2011;30(2):58-64.

6. Scagliusi FB, Garcia MT, Indiani ALC, Cardoso MA. Relative validity of a food frequency questionnaire developed to assess food intake of schoolchildren living in the Brazilian Western Amazon. Cad Saude Publica. 2011;27(11):2197-206. DOI: http://dx.doi.org/10.1590/S0102-311X2011001100013

7. Matos SM, Prado MS, Santos CA, D'Innocenzo S, Assis AM, Dourado LS, et al. Validation of a food frequency questionnaire for children and adolescents aged 4 to 11 years living in Salvador, Bahia. Nutr Hosp. 2012; 27(4):1114-9. DOI: http://dx.doi.org/10.3305/nh.2012.27.4.5883

8. Willett WC. Nutritional Epidemiology. New York: Oxford University Press, 1998.

9. Hinnig PF, Mariath AB, Freaza SEM, Gambardella AMD, Bergamaschi DP. Construção de um Questionário de Frequência Alimentar Quantitativo para crianças de 7 a 10 anos. Rev Bras Epidemiol. 2014;17(2):479-94. DOI: http://dx.doi.org/10.1590/1809-4503201400020015ENG

10. Machin D, Campbell M, Fayers P, Pinol A. Sample size table for clinical studies. 2ed. Oxford: Blackwell Scientific Publications; 1997.

11. Associação Brasileira de Empresas de Pesquisa (ABEP). Critério Padrão de Classificação Econômica/ Brasil. 2008. [cited 2011 Nov 25] Available from: file:///C:/Users/User/Downloads/CCEB\%202008\%20 \%20Em\%20vigor\%20em\%202008\%20(base\%20LSE\%202005).pdf

12. Zabotto CB, Vianna RPT, Gil MF. Registro fotográfico para inquéritos dietéticos: utensílios e porções. Goiânia: Nepa/Unicamp; 1996.

13. Willett W, Stamfer MJ. Total energy intake: implications for epidemiological analyses. Am J Epidemiol. 1986;124(1):17-27.

14. Watson JF, Collins CE, Sibbritt DW, Dibley MJ, Garg ML. Reproducibility and comparative validity of a food frequency questionnaire for Australian children and adolescents. Int J Behav Nutr Phys Act. 2009; 6:62. DOI: http://dx.doi.org/10.1186/1479-5868-6-62

15. Block G. A review of validations of dietary assessment methods. Am J Epidemiol. 1982;115(4):492-505. DOI: https://dx.doi.org/10.1093/oxfordjournals.aje.a113331

16. Romieu I, Stampfer MJ, Stryker WS, Hernadez M, Kaplan L, Sober A, et al. Food predictors of betacarotene and alpha- tocopherol: validation of a food frequency questionnaire. Am J Epidemiol. 1990;131(5):864-76.

17. Gibson, RS. Principles of Nutritional Assessment. Oxford: Oxford University Press, 1990.

18. Nelson M. The validation of dietary questionnaires. In: Margetts BM, Nelson M. Design Concepts in Nutritional Epidemiology. 2.ed. Oxford: Oxford University Press, 1997. 
19. McPherson RS, Hoelscher DM, Alexander M, Scanlon KS, Serdula MK. Dietary assessment methods among school-aged children: validity and reliability. Prev Med. 2000;31(2):S11-33. DOI: https://dx.doi.org/10.1006/pmed.2000.0631

20. Beaton $\mathrm{GH}$. Interpretation of results from diet history studies. In: Kohlmeier L. The Diet History Method. Proceedings of the 2nd Berlin Meeting on Nutritional Epidemiology. London: Smith-Gordon; 1989.

21. Rockett HR, Colditz GA. Assessing diets of children and adolescents. Am J Clin Nutr. 1997;65(4 Supl):S1116-22. DOI: https://dx.doi.org/ 10.1093/ajcn/65.4.1116S

22. Serdula MK, Alexander MP, Scanlon KS, Bowman BA. What are preschool children eating? A review of dietary assessment. Annu Rev Nutr. 2001;21:475-98. DOI: https://dx.doi.org/ 10.1146/annurev.nutr.21.1.475

23. Sahashi Y, Tsuji M, Wada K, Tamai Y, Nakamura K, Nagata C. Validity and reproducibility of food frequency questionnaire in Japanese children aged 6 years. J Nutr Sci Vitaminol. 2011;57(5):372-6.

24. Livingstone MB, Robson PJ. Measurement of dietary intake in children. Proc Nutr Soc. 2000;59(2):27993. DOI: https://dx.doi.org/10.1017/S0029665100000318

25. Subar AF, Dodd KW, Guenther PM, Kipnis V, Midthune D, McDowell M, et al. The food propensity questionnaire: concept, development, and validation for use as a covariate in a model to estimate usual food intake. J Am Diet Assoc. 2006;106(1):1556-63. DOI: https://dx.doi.org/10.1016/j.jada.2006.07.002

\section{Resumo}

Introdução: Um Questionário de Frequência Alimentar Quantitativo (QUEFAC) foi construído por Hinnig et al. para avaliar a dieta habitual de crianças de 7 a 10 anos, uma vez que os desenvolvidos para adultos podem superestimar o consumo de crianças. Porém, precisa ser testado quanto sua validade e reprodutibilidade para se afirmar que o instrumento apresenta qualidade reconhecida.

Objetivo: Avaliar a reprodutibilidade e a validade do QUEFAC em crianças de 7 a 10 anos.

Método: A reprodutibilidade foi realizada com 89 crianças que responderam a dois QUEFAC's. A validade foi realizada com 167 crianças que responderam a três Recordatórios de 24 horas (método de referência) e a um QUEFAC. Para avaliação, utilizaram-se o teste t pareado e Wilcoxon, os coeficientes de correlação intraclasse e Kappa ponderado e análise dos gráficos de Bland-Altman.

Resultados: Para reprodutibilidade, observou-se diferença de médias para todos os nutrientes investigados, os coeficientes de correlação variaram de 0,12 a 0,54 e os valores de Kappa de 0,01 a 0,39 . Na validade, observou-se diferença de média para todos os nutrientes, com exceção da energia e zinco, os coeficientes de correlação variaram de 0 a 0,37, valores de Kappa de 0 a 0,27 e gráficos de Bland-Altman mostraram distribuição aleatória para a maioria dos nutrientes investigados.

Conclusão: O QUEFAC não se mostrou válido para avaliação da dieta habitual dos últimos três meses em crianças de 7 a 10 anos em São Paulo e apresentou moderada reprodutibilidade para energia, proteínas, cálcio, fósforo, ferro, potássio, magnésio e vitamina B2.

Palavras-chave: consumo de alimentos, criança, questionários, validade dos testes, reprodutibilidade dos testes, avaliação nutricional.

${ }^{\oplus}$ The authors (2018), this article is distributed under the terms of the Creative Commons Attribution 4.0 International License (http:// creativecommons.org/licenses/by/4.0/), which permits unrestricted use, distribution, and reproduction in any medium, provided you give appropriate credit to the original author(s) and the source, provide a link to the Creative Commons license, and indicate if changes were made. The Creative Commons Public Domain Dedication waiver (http://creativecommons.org/publicdomain/zero/ $1.0 /$ ) applies to the data made available in this article, unless otherwise stated. 